\title{
Efficiency of Slow Sand Filter in Purifying Well Water
}

\author{
Timoteo B. Bagundol ${ }^{1}$, Anthony L. Awa ${ }^{2}$, Marie Rosellynn C. Enguito ${ }^{2}$ \\ ${ }^{1}$ College of Engineering and Technology, Misamis University, Ozamiz City, Philippines \\ ${ }^{2}$ Natural Science Department, College of Arts and Sciences, Misamis University, Ozamiz City, \\ Philippines \\ Corresponding email: Timbag2005@yahoo.com
}

\begin{abstract}
Slow sand filter can be effective for water purification. The formation of "schmutzdecke" on the surface of the sand bed can vary the efficiency of slow sand filter. This study aimed to investigate the efficiency of slow sand filter in purifying well water using Labo River sand as the filter medium. Bacteriological analysis and turbidity tests were done on water samples from deep and shallow well before and after filtration at $0.30 \mathrm{~m}, 0.60 \mathrm{~m}$ and $0.90 \mathrm{~m}$ filter depths and at $200 \mathrm{~L} / \mathrm{hr} . \mathrm{m}^{2}, 300 \mathrm{~L} / \mathrm{hr}^{\mathrm{m}} \mathrm{m}^{2}$ and $400 \mathrm{~L} / \mathrm{hr}^{\mathrm{m}} \mathrm{m}^{2}$ flow-through rates. Percent removal of $E$. coli varied and efficiency was generally high at different depths and flowthrough rates. However, E. coli removal in different filter depths and flowthrough rates was not significant $(\mathrm{p}<0.05)$. Percent efficiency in reducing turbidity varied. Efficiency was increasing at increasing depths and flow-through rates. There was a significant difference on the efficiency to reduce turbidity among different sand filter depths $(\mathrm{p}<0.05)$. However, there was no significant difference on the efficiency to reduce turbidity among the three flow-through rates. A significant interaction between filter depth and the flow-through rate in the removal of E. coli $(\mathrm{p}<0.05)$ was observed which means that increasing the depth of the sand filter while slowing the filtration rate improved efficiency in $E$. coli removal of the raw water. Most of the bacteria and particle removal is ascribed to schmutzdecke development. This study can help address the water problem particularly in local communities that depend greatly on well water for drinking.
\end{abstract}

Keywords: E. coli, filtration, Labo River, schmutzdecke, turbidity 


\section{Introduction}

Groundwater contamination threatens its sustainable use as the biggest reservoir of clean water (Lee, 2011). The importance of groundwater in developing countries as the primary source of water for human consumption, domestic and agriculture uses is challenged by various forms of pollution that are mostly human-caused (Bann \& Wood, 2012; Lee, 2011). Contamination of groundwater with harmful wastes and potentially pathogenic bacteria particularly in urban areas is deleterious to human health (Abdullah et al., 2012). In the Philippines, most water supply source is groundwater especially in rural areas where the cost of treated water is unaffordable to low-income local residents.

There is a primary public concern in using vulnerable groundwater for drinking without water purification or disinfection measures (Pitkänen et al., 2011) along with the general belief among the local population that groundwater is pathogen-free and safe to drink (Sandhu et al., 2011). Microbial contamination in drinking water therefore requires sanitation interventions and treatments that eliminate harmful bacteria (Coleman et al., 2013; Escamilla et al., 2013).

Slow sand filtration is a simple technology used for pathogen and particle removal in drinking water purification (Langenbach et al., 2009). The slow sand filter was also tried in biological denitrification of drinking water (Aslan \& Cakici, 2007). The physical, chemical and biological means of removing bacteria and suspended particles in raw water can be done using slow sand filter (Bauer et al., 2011; Ijadunola et al., 2011; Langenbach et al., 2009; Hipshear, 2011). Straining, sedimentation, inertial impaction, interception, adhesion, flocculation, diffusion, adsorption and biological activity have been suggested as mechanisms of contaminant removal in filtration (Anderson et al., 1985). The findings of the study of Dastanaie et al. (2007) revealed that the overall function of the filter in removing total suspended solids is acceptable and the processes found in sand filters replicate many of those found in natural sand banks and sandy beaches (Wotton, 2002).

Formation of schmutzdecke or colmation layer on the surface of the sand bed as filtration progresses is considered as the important process of purification mechanism of slow sand filters (Farooq, 1994). Protozoa, bacteria, algae and other forms of life within the filter bed contribute to pollutant removal (Banda, 2011; Hsieh et al., 2010; Joubert et al., 2008 Bonnefoy, 2002) including E. coli (Mwabi et al., 2013). 
The mechanisms of purification vary depending on the type of filter. Proper choice of the filter depth, sand type, sand size and filtration rate affects the pollutant removal performance and purification efficiency of the sand filter (Abudi, 2011).

The biological activity is enhanced with increasing filter depths. Microorganisms and other suspended particles have to travel more through the sand, thus, a higher removal efficiency is expected at higher sand depths (Ellis, 1984).

The use of slow sand filter to remove bacteria from contaminated groundwater has been an attractive option as a filter system in both developed and developing countries especially in rural communities due to its low cost, ease of operation and minimal maintenance requirements (Nassar \& Hajjaj, 2013; Logsdon et al., 2002). In European countries, some water purifier manufacturers claimed their products have been using a filtering medium, such as sand, from a chosen source outside the country to produce potable water.

Using sand filter for water treatment offers unique advantage for solving water shortage problem. Though the technology is cheap and simple, it is not widely used in the Philippines, perhaps due to lack of expertise for the maintenance and operations of such kind of treatment. With the growing population in the Philippines especially in the urban and suburban areas, potable water demand will increase inevitably and slow sand filtration may address the concern. Moreover, access to safe drinking water is one of the first priorities following a disaster in a local community (Loo et al., 2012).

An evaluation of the use of local sand for slow filtration and its eventual use in local water districts for water treatment is an important contribution to water demand of the local population. Thus, this study aimed to investigate the efficiency of slow sand filter in purifying well water using Labo River sand as the filter medium. Bacteriological analysis and turbidity tests were done on water sample before and after the filtration process to determine the percent efficiency of the slow sand filter to remove $E$. coli and to reduce turbidity readings at different filter depths and flow-through rates respectively. 


\section{Materials and Methods}

\section{Filter Media Preparation}

The filter used in this study was fine sand with minimal clay, loam and organic matter contents from Labo River in Misamis Occidental, Philippines. The sand was screened using fish net to remove some bigger sizes and washed with water before grading to remove some clay and dirt content. The sand was sun-dried and graded according to the required specification. Sand particles with $0.16 \mathrm{~mm}$ to $0.30 \mathrm{~mm}$ sizes or particles passing sieve no. 50 and those retained in sieve no. 100 were used. Sieves used were based on U.S. Standard Sieve Sizes.

\section{Filter Prototype}

The filter apparatus was locally manufactured in this study (Figures 1a \& 1b). It consists of the following: 1.80 meters height cylindrical tank made of polyvinyl chloride (PVC) pipe with 0.30 meter diameter that is supported on a metal base with an elevated platform for ease in observation inside, a drain pipe with 0.012 meter diameter made of galvanizing iron (G.I.) with perforations at its segments within the tank to serve as inlets of the filtrate, two valves: a primary valve that regulates the filtrate flow through the drain pipe and a secondary valve that shuts off filter operation, and a water level indicator made of clear plastic hose that is installed between the tank and the primary control valve to mark the filter status. The water levels describe the filter status as $\mathrm{A}-$ filter not in operation, B - clean filter in operation, $\mathrm{C}$ - filtering and D - filter needs cleaning.

Graded gravel from Labo River was used as support of the sand filter. Gravel with sizes from about $25.5 \mathrm{~mm}$ to $31.7 \mathrm{~mm}$, passing and retained in sieves no. $1 \frac{1 / 4}{4}$ and no. 1 respectively was placed at the bottom of the tank. Gravel passing through sieve no. 1 and retained in sieve no. $3 / 8$ (sizes 9.6 - $25.4 \mathrm{~mm}$ ) was placed at the middle. Those passing in sieve no. $3 / 8$ and retained in sieve 8 (sizes $2-37-9.5 \mathrm{~mm}$ ) was placed at the top immediately below the sand filter. Each layer of the graded gravel is 100- mm thick or a total gravel depth of $300 \mathrm{~mm}$. The gravel layer holds the sand filter to prevent it from displacement during filtration (Liabwel et al., 2001; Mwabi et al., 2013). After grading and before placing in the filter set-up, both sand and gravel were washed again thoroughly with clean water to assure that both materials were free of any foreign matter. 


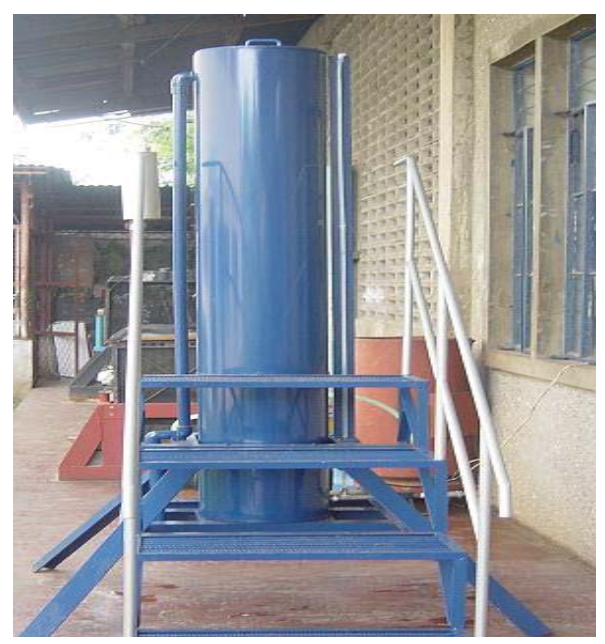

a. Slow sand filter apparatus

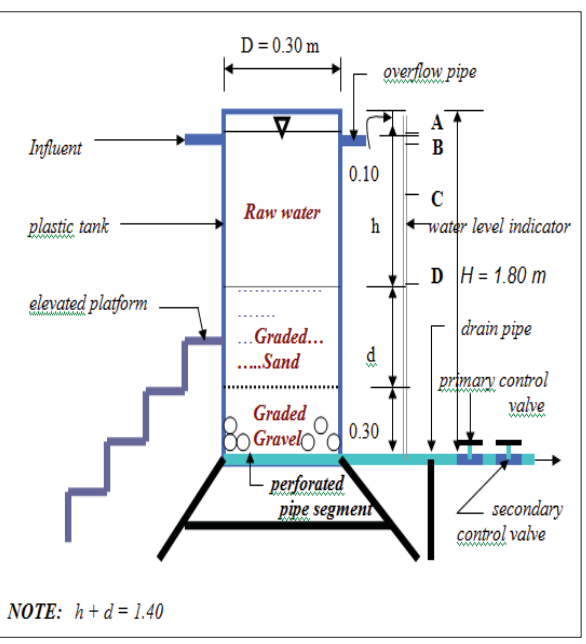

b. Schematic diagram of filter

Figure 1. Slow sand filter prototype.

\section{Filter Depth and Flow-through Rates}

The filter depth was varied at $0.30 \mathrm{~m}, 0.60 \mathrm{~m}$ and $0.90 \mathrm{~m}$ and the filter was operated at three different flow-through rates per square meter $\left(\mathrm{m}^{2}\right)$ of filter area. The rates were computed based on the sectional area (A) of tank filter which was $0.0707 \mathrm{~m}^{2}$ and the actual discharges of 0.004 $\mathrm{L} / \mathrm{s}, 0.006 \mathrm{~L} / \mathrm{s}$ and $0.008 \mathrm{~L} / \mathrm{s}$. These calculations correspond to flowthrough rates of $200 \mathrm{~L} / \mathrm{hr}^{2} \mathrm{~m}^{2}, 300 \mathrm{~L} / \mathrm{hr}^{2} \mathrm{~m}^{2}$ and $400 \mathrm{~L} / \mathrm{hr}^{2} \mathrm{~m}^{2}$ respectively.

Adequate time was considered for the water particles to travel through the bed before the filtrate was collected at a point for bacteriological analysis. The approximate total time required for a water particle to travel was the sum of travel time required in each segment along its path of flow. The minimum time interval $(\mathrm{T})$ for the particle to travel to the next point where filtrate could be collected after varying the discharge in hours was determined using the formula: $\mathrm{T}=\left(\mathrm{L}_{\mathrm{t}} / \mathrm{V}_{\mathrm{t}}+\mathrm{L}_{\mathrm{p}} / \mathrm{V}_{\mathrm{p}}\right) /$ 3600, where: $\mathrm{L}_{\mathrm{t}}=$ length of tank segment from sand bed to drain pipe in $\mathrm{m}$.; $\mathrm{L}_{\mathrm{p}}=$ length of pipe segment from tank to the point where filtrate could be collected in $\mathrm{m}$; $\mathrm{V}_{\mathrm{t}}=$ velocity of water in the tank in $\mathrm{m} / \mathrm{s} . ; \mathrm{V}_{\mathrm{p}}=$ velocity of water in the pipe in $\mathrm{m} / \mathrm{s}$.; and, $\mathrm{V}=\mathrm{Q} / \mathrm{A}$, where: $\mathrm{V}=$ velocity of flow in $\mathrm{m} / \mathrm{s} ; \mathrm{Q}=$ discharge, in $\mathrm{m}^{3} / \mathrm{s} ; \mathrm{A}=$ cross-sectional area of flow, in $\mathrm{m}^{2}$. 


\section{Source of Raw Water}

Raw water from a deep well in Misamis University located few meters from an old septic tank and near an adjoining hospital was analyzed for E. coli count before and after the filtration process. Raw water from a shallow well near the Engineering Laboratory in the campus was tested for turbidity before and after the filtration process. A different source of raw water with high turbidity was used for the turbidity test in order to determine the efficiency of the slow sand filter in reducing turbidity.

A motorized pump was used to deliver raw water from the deep well to the elevated tank. From the elevated tank, water flowed down by gravity to a faucet where a hose was used to supply water to the filter apparatus. A motor pump was used to directly deliver water from shallow well to the filter apparatus.

\section{System Operation and Sample Collection}

The filter prototype which already contained the bed of gravel was filled with the graded Labo River sand at $0.90 \mathrm{~m}$ thick. Potable water was initially supplied to the tank through its bottom (backwash) at a level of the sand surface using a motorized pump. This was done to remove any trapped air between voids of the filter medium which could resist the gravity flow of raw water through the filter.

During tank filling, the control valves were opened and at very low rate, the water was allowed to flow through the filter. An elapsed time of two weeks was considered for schmutzdecke (biofilm layer) to develop at the sand surface (Joubert et al., 2008). A series of preliminary bacteriological analyses was conducted to determine the development of the schmutzdecke as the filtration process progresses. When biological filtering process was occurring as indicated on the bacterological analyses, the filter was ready for bacteriological testing proper. The filter was operated at three different rates.

Samples were collected using sterilized $500 \mathrm{ml}$ plastic bottles from both the influent and the filtrate (effluent) from the drain pipe. The collected samples for bacteriological analysis were placed in an ice box with ice cubes to maintain the temperature at $4^{0} \mathrm{C}$. The bottles were numbered, labeled and transported to the laboratory for analysis in terms of $E$. coli count using multiple tube fermentation method. Turbidity test was also done to investigate the efficiency of the sand filter in reducing turbidity. Trial and error method by direct volume measurement was used 
in setting the flow rates. Known volume of sample was collected and the elapsed time was recorded. Thus, $\mathrm{Q}=\mathrm{Vol} / \mathrm{t}$, where: $\mathrm{Q}=$ volume flow rate in $\mathrm{L} / \mathrm{s}, \mathrm{Vol}=$ volume of sample collected in liters; and $\mathrm{t}=$ elapsed time in seconds.

To setup the filter depth at 0.6 meter, the upper sand at 0.90 meter depth was removed up to 0.5 meter and fresh Labo River sand was added up to a total filter depth of $0.60 \mathrm{~m}$. The upper $10 \mathrm{~cm}$ of sand was properly removed as most of the biological layer (schmutzdecke) was concentrating at this depth. Raw water from the same source used previously in the $0.9 \mathrm{~m}$ sand filter depth was supplied to the tank through its inlet up to 0.5 $\mathrm{m}$ depth. An elapsed time of two weeks was considered for schmutzdecke to develop at the sand surface. The filter was operated at three different rates. The same procedures were done for sample collection, bacteriological analysis and turbidity test.

To setup the filter depth at 0.3 meter, the upper sand at 0.60 meter depth was removed up to 0.2 meter and fresh Labo River sand was added up to a total filter depth of $0.30 \mathrm{~m}$. Groundwater from the same source used previously in the $0.9 \mathrm{~m}$ sand filter depth was supplied to the tank through its inlet up to $0.2 \mathrm{~m}$ depth. An elapsed time of two weeks was considered for schmutzdecke to develop at the sand surface. The filter was operated at three different rates. The same procedures were done for sample collection, bacteriological analysis and turbidity test.

\section{Statistical Method and Analysis}

The statistical method used in this experimental study was Two-Way ANOVA. There were three levels of factor A (filter depth) and three levels of factor B (flow-through rate), and these were arranged in a factorial design.

\section{Results and Discussion}

\section{E. coli Removal}

Results of bacteriological analysis of raw water at different depths and flow-through rates of the sand filter are shown in Table 1. The E.coli count in influent exceeds the national standard for fecal coliform for drinking water (DOH, 2007). Reduction in E. coli count in MPN per $100 \mathrm{ml}$ was observed using slow sand filter. Percent removal of E. coli of the slow sand filter varied and was generally high at different depths and flow-through rates (Figure 2). However, at $300 \mathrm{~L} / \mathrm{hr}^{\mathrm{m}} \mathrm{m}^{2}$ flow rate, removal 
efficiency is opposite in pattern relative to the other two rates that follow the same trend. The height of the sand filter through which water passes is crucial to filtration efficiency. However, the removal efficiency of sand bed depends more upon the maturity of the schmutzdecke than upon its depth (AWWA, 1991). Within the filter bed, the presence of protozoa, bacteria, algae and other forms of life contributes to the removal of pollutants (Banda, 2011; Bonnefoy, 2002) including the E. coli (Mwabi et al., 2013).

Table 1. E. coli average count (MPN/100 ml) and percent removal efficiency of slow sand filter at different filter depths and flow-through rates.

\begin{tabular}{|c|c|c|c|c|c|c|c|c|}
\hline \multirow[t]{2}{*}{$\begin{array}{l}\text { Depth of } \\
\text { filter }\end{array}$} & \multirow{2}{*}{$\begin{array}{c}\text { Raw } \\
\text { Water } \\
\text { (MPN/ } \\
100 \mathrm{~mL} \text { ) }\end{array}$} & \multicolumn{6}{|c|}{$\begin{array}{c}\text { Flow-through rate }\left(\mathrm{L} / \mathrm{hr} . \mathrm{m}^{2}\right) \text { and } E \text {. coli removal } \\
\text { efficiency }(\%)\end{array}$} & \multirow[t]{2}{*}{$\begin{array}{c}\text { Permissible } \\
\text { level }\end{array}$} \\
\hline & & 200 & $\begin{array}{l}\text { Removal } \\
\text { efficiency }\end{array}$ & 300 & $\begin{array}{l}\text { Removal } \\
\text { efficiency }\end{array}$ & 400 & $\begin{array}{l}\text { Removal } \\
\text { efficiency }\end{array}$ & \\
\hline $\mathrm{d}=0.30 \mathrm{~m}$ & 4.77 & 0 & 100.0 & 1.47 & 69.18 & 0 & 100.0 & $<1.1$ \\
\hline $\mathrm{d}=0.60 \mathrm{~m}$ & 16 & 1.47 & 90.81 & 0 & 100.0 & 1.7 & 89.34 & $<1.1$ \\
\hline $\mathrm{d}=0.90 \mathrm{~m}$ & 16 & 0 & 100.0 & 0.73 & 95.43 & 0 & 100 & $<1.1$ \\
\hline
\end{tabular}

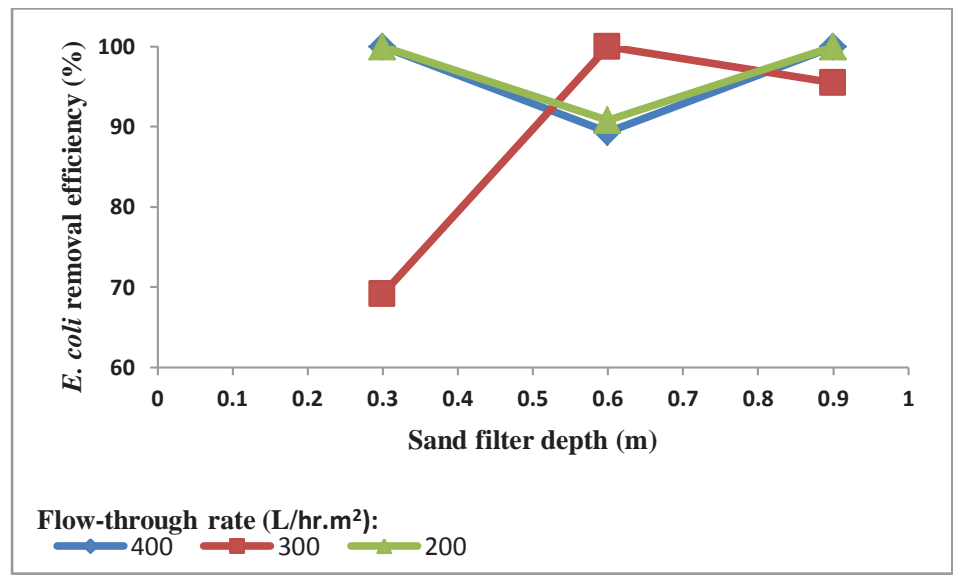

Figure 2. E. coli removal efficiency $(\%)$ at different sand filter depths (m) and flow-through rates $\left(\mathrm{L} / \mathrm{hr} . \mathrm{m}^{2}\right)$

Two-way ANOVA reveals that there is no significant difference on the removal of $E$. coli among the three different sand filter depths and flow-through rates $(\mathrm{p}<0.05)$. The E. coli removal efficiency of the sand varies at different filter depths and flow-through rates but the difference is 
not significant. The opposite pattern of removal efficiency at $300 \mathrm{~L} / \mathrm{hr}^{2} \mathrm{~m}^{2}$ relative to the other two flow rates is not significant. This study shows that the development of the schmutzdecke layer is responsible for the removal of $E$. coli regardless of filter depth and flow-through rates.

Biological activity and protistan abundance at the top layer of the schmutzdecke could probably be the mechanism of E. coli removal in water. The role of protistan predation may have an influence on bacterial removal but further studies have to confirm this relationship. In the study of Unger and Collins (2006), E. coli removal in slow-rate biological filters occured primarily at the interface and was related to schmutzdecke biological activity and protistan abundance. Elliott et al. (2011) also noted that the activity of the microbial community within the filter is responsible for the reduction of pathogens and that the most likely biological pathway is the production of microbial exoproducts such as proteolytic enzymes or grazing of bacteria and higher microorganisms on other organisms. In the study of Hijnen et al. (2007), the role of predation on the biofilm was also contributing to the removal of other protozoans in water.

E. coli may be removed through a combination of biological and physical processes that take place in the schmutzdecke and within the sand layer. The bacteria may become mechanically trapped in the spaces between the sand grains. Adsorption also may facilitate the removal of $E$. coli as it can become attached to each other or the bacteria may die because of food scarcity and oxygen depletion (CAWST, 2009). In the study of Joubert et al. (2008), visualization of the microbial colonization of a slow sand filter using an environmental scanning electron microscope revealed that the mature, ripened filter exhibited a dense extracellular matrix consisting of a wide variety of microorganisms and their extracellular and breakdown products.

\section{Turbidity reduction}

Results of turbidity test of raw water at different depths and flowthrough rates of the sand filter are shown in Table 3. Turbidity readings exceed the national standard (DOH, 2007). Significant reduction of turbidity readings was observed. Percent efficiency of slow sand filter in reducing turbidity varied and was increasing at different depths and flowthrough rates (Figure 3). Most of the particle removal is ascribed to schmutzdecke (AWWA, 1991). Biofilm formation plays a key role in the transport of suspended particles. The presence of the biofilm significantly increased the deposition of particles at a particular flow rate thereby 
reducing the particle concentrations in the water (Arnon et al., 2010). Mechanical trapping and adsorption of suspended particles coud be the mechanism for the reduction of turbidity. As water passes through the Schmutzdecke, suspended particles may be trapped in the filter and dissolved organic material is adsorbed and metabolised by microorganisms such as bacteria, fungi and protozoa (CAWST, 2009; Linlin et al., 2011). The sand filter is not also only effective for relatively less contaminated water in reducing turbidity but can also be used for wastewater treatment for reuse (Abdel-Shafy et al., 2013; Rehman et al., 2012; Bomo et al., 2003) and for removal of antimicrobial contaminants in source water (Rooklidge et al., 2005).

Table 3. Average turbidity of raw water samples (NTU) and percent efficiency of slow sand filter to reduce turbidity at different filter depths and flow-through rates

\begin{tabular}{|c|c|c|c|c|c|c|c|c|}
\hline \multirow{2}{*}{$\begin{array}{l}\text { Depth of } \\
\text { filter }\end{array}$} & \multirow{2}{*}{$\begin{array}{c}\text { Raw } \\
\text { Water } \\
\text { (MPN/ } \\
100 \mathrm{~mL})\end{array}$} & \multicolumn{6}{|c|}{ Flow-through rate $\left(\mathrm{L} / \mathrm{hr} . \mathrm{m}^{2}\right)$ and $E$. coli removal efficiency (\%) } & \multirow{2}{*}{$\begin{array}{l}\text { Permissible } \\
\text { level (NTU) }\end{array}$} \\
\hline & & 200 & $\begin{array}{c}\text { Efficiency to } \\
\text { reduce } \\
\text { turbidity } \\
\end{array}$ & 300 & $\begin{array}{c}\text { Efficiency to } \\
\text { reduce } \\
\text { turbidity } \\
\end{array}$ & 400 & $\begin{array}{c}\text { Efficiency to } \\
\text { reduce } \\
\text { turbidity } \\
\end{array}$ & \\
\hline $\mathrm{d}=0.30 \mathrm{~m}$ & 24.00 & 0.23 & 99.04 & 0.22 & 99.08 & 0.25 & 98.96 & 5 \\
\hline $\mathrm{d}=0.60 \mathrm{~m}$ & 38.45 & 0.34 & 99.12 & 0.30 & 99.22 & 0.30 & 99.22 & 5 \\
\hline $\mathrm{d}=0.90 \mathrm{~m}$ & 103.0 & 0.44 & 99.58 & 0.42 & 99.59 & 0.35 & 99.66 & 5 \\
\hline
\end{tabular}

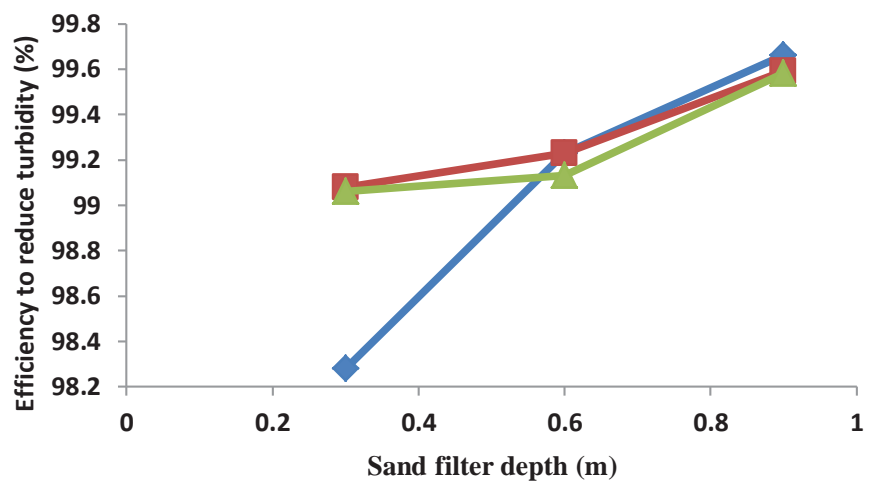

Flow-through rate $\left(\mathrm{L} / \mathrm{hr} \cdot \mathrm{m}^{2}\right)$ :

$\longrightarrow 400 \simeq 300 \simeq 200$

Figure 3. Efficiency of slow sand filter $(\%)$ to reduce turbidity at different sand filter depths (m) and flow-through rates (L/hr.m²). 
Two-way ANOVA reveals that there is a significant difference on the efficiency of slow sand filter to reduce turbidity in raw water among the three different sand filter depths $(p<0.05)$. Efficiency of reducing turbidity in filtrate was higher using sand filter of $0.90 \mathrm{~m}$ and $0.60 \mathrm{~m}$ depth than in $0.30 \mathrm{~m}$. The findings of Torrens et al. (2009) revealed that the deeper filters presented better removals of contaminants due to higher hydraulic detention times. However, there is no significant difference on the efficiency of slow sand filter to reduce turbidity in raw water among the three flow-through rates. The research results during three days of infiltration show that the sand filter can remove fecal coliform bacteria at a depth of $150 \mathrm{~cm}$, and provide purified water with a concentration of suspended solids less than $20 \mathrm{mg} /$ liter at a depth of $75 \mathrm{~cm}$.

Variance analysis also shows a significant interaction between filter depth and the flow-through rate in the removal of E. coli $(\mathrm{p}<0.05)$. This interaction is not observed between filter depth and flow rate in reducing turbidity. Findings indicate that increasing the depth of the sand filter while slowing the filtration rate improves efficiency in E. coli removal from raw water.

\section{Conclusion and Recommendations}

Purification of well water using Labo River sand as a medium in slow sand filter is feasible. The efficiency of the filter to remove E. coli and reduce turbidity varied and was generally high at different filter depths and flow-through rates. This can be attributed to the formation of schmutzdecke on the sand surface and adsorption process. Efficiency variation of sand filter to remove $E$. coli at $0.3 \mathrm{~m}, 0.6 \mathrm{~m}$ and 0.9 filter depths and at $200 \mathrm{~L} / \mathrm{hr} . \mathrm{m}^{2}, 300 \mathrm{~L} / \mathrm{hr} . \mathrm{m}^{2}$ and $400 \mathrm{~L} / \mathrm{hr} . \mathrm{m}^{2}$ flow-through rates is not significant. It signifies that slow sand filter is effective in removing $E$. coli at these depths and flow rates. Biological activity and protistan abundance on the top layer of the schmutzdecke along with adsorption and mechanical trapping of microorganisms could probably be the mechanisms of E. coli removal in water at different depths and flow rates. However, the variation in efficiency of slow sand filter to reduce turbidity at $0.3 \mathrm{~m}, 0.6 \mathrm{~m}$ and 0.9 filter depths is significant. This means that the efficiency to reduce turbidity increases with increasing filter depth. This does not hold true at different flow-through rates. Slow sand filter is effective in reducing turbidity irrespective of varying flow rates (i.e., $200 \mathrm{~L} / \mathrm{hr} . \mathrm{m}^{2}, 300 \mathrm{~L} / \mathrm{hr} . \mathrm{m}^{2}$ and $400 \mathrm{~L} / \mathrm{hr} . \mathrm{m}^{2}$, respectively) The 
interaction between filter depth and the flow-through rate in the removal of $E$. coli is significant which indicates that increasing the depth of the sand filter while slowing the filtration rate improved efficiency in $E$. coli removal. This interaction is not observed between filter depth and flow rate in the reducing turbidity.

A study on continuous filtration process for a given period of time can further investigate the optimum efficiency of slow sand filter in water purification. Isolating bacteria in schmutzdecke may provide further knowledge on the efficiency of slow sand filter in water purification.

\section{Acknowledgment}

The authors are thankful to Misamis University for the research grant.

\section{Literature Cited}

Abdel-Shafy, H. I., El-Khateeb, M. A., \& Shehata, M. (2013). Greywater treatment using different designs of sand filters. Desalination and Water Treatment, (ahead-of-print), 1-6.

Abdullah, S., Iqbal, M. A., Ilyas, M., \& Rehana, A. (2012). Groundwater pollution at Beed, Maharashtra as an effect of MSW dumping. Bulletin of Environment, Pharmacology and Life Sciences, 1(12), 43-46.

Abudi, Z. N. (2011). The effect of sand filter characteristics on removal efficiency of organic matter from grey water. Al-Qadisiya Journal for Engineering Sciences, 4(2), 143-155.

Anderson, D., Siegrist, R., \& Otis, R. (1985). Technology assessment of intermittent sand filters. EPA No. 832R85100.

Arnon, S., Marx, L. P., Searcy, K. E., \& Packman, A. I. (2010). Effects of overlying velocity, particle size, and biofilm growth on streamsubsurface exchange of particles. Hydrological Processes, 24(1), 108114. 
Aslan, S. \& Cakici, H. (2007). Biological denitrification of drinking water in a slow sand filter. Journal of Hazardous Materials, 148, (1-2), 253-258.

AWWA (1991). Manual of Design for Slow Sand Filtration. Retrieved from http://protosh2o.act.be/VIRTUELE_BIB/Watertechniek/350_ Water behandeling/353.1_HEN_E5_Manual_Design.pdf.pdf

Banda, I. (2011, Feb 2). Zimbabwe: Filtering fact from fiction about D.I.Y. water treatment. Inter Press Sevice News Agency. Retrieved from http://www.ipsnews.net/2011/02/zimbabwe-filtering- factfrom- fiction- about-diy-water-treatment/

Bann, C., \& Wood, S. C. (2012). Valuing groundwater: A practical approach for integrating groundwater economic values into decision making-A case study in Namibia, Southern Africa. Water SA, 38(3), 461-466.

Bauer, R., Dizer, H., Ingeborg, G., Karl-Heinz, R., \& Pila, J.M.L. (2011). Removal of bacterial fecal indicators, coliphages and enteric adenoviruses from waters with high fecal pollution by slow sand filtration. Water Research, 45(2), 439-452.

Bomo, A. M., Husby, A., Stevik, T. K., \& Hanssen, J. F. (2003). Removal of fish pathogenic bacteria in biological sand filters. Water Research, 37(11), 2618-2626.

Bonnefoy, P. (2002). Coping with water crisis in Cuba. Appropriate Technology, 29(2), 56-7.

Centre for Affordable Water and Sanitation Technology (CAWST) (2009). Biosand Filter Manual: Design, Construction, \& Installation. Retrieved from http://www.ctahr.hawaii.edu/hawaiirain/Library /Guides \&Manuals/CAWST \%20files /Biosand\% 20Filter\% 20 Manual_Version \% 2010Sep\% 2009[1].pdf 
Coleman, B. L., Louie, M., Salvadori, M. I., McEwen, S. A., Neumann, N., Sibley, K., ... \& McGeer, A. J. (2013). Contamination of Canadian private drinking water sources with antimicrobial resistant Escherichia coli. Water Research, 47(9), 3026-3036.

Dastanaie, A. J., Bidhendi, G. N., Nasrabadi, T., Habibi, R., \& Hoveidi, H. (2007). Use of horizontal flow roughing filtration in drinking water treatment. International Journal of Environmental Science and Technology, 4(3), 379-382.

DOH. (2007). Administrative Order 2007-0012. Philippine National Standards for Drinking Water. Retrieved from http://spsissuances. da.gov.ph/attachments/article/229/ao2007-0012.pdf

Elliott, M. A., DiGiano, F. A., \& Sobsey, M. D. (2011).Virus attenuation by microbial mechanisms during the idle time of a household slow sand filter. Water Research, 45 (14), 4092-4102.

Ellis, V. (1984). Slow sand filtration. CRC Critical Reviews in Environmental Control, 5(4), 315-354.

Escamilla, V., Knappett, P. S., Yunus, M., Streatfield, P. K., \& Emch, M. (2013). Influence of latrine proximity and type on tubewell water quality and diarrheal disease in Bangladesh. Annals of the Association of American Geographers, 103(2), 299-308.

Farooq, S. H., Al-Yousef, A. K., Al-Layla, R. I., \& Ishaq, A. M. (1994). Tertiary treatment of sewage effluent via pilot scale slow sand filtration. Environmental Technology, 15(1), 15-28.

Hijnen, W. A., Dullemont, Y. J., Schijven, J. F., Hanzens-Brouwer, A. J., Rosielle, M., \& Medema, G. (2007). Removal and fate of Cryptosporidium parvum, Clostridium perfringens and small-sized centric diatoms Stephanodiscus hantzschii in slow sand filters. Water research, 41(10), 2151-2162. 
Hipshear, T. (2011). Modeling Biological and Chemical Processes in Slow Sand Filtration. Retrieved from https://aiche.confex.com/aiche/ 2010asc /webprogram/Paper210185.html

Hsieh, S. T., Lin, T. F., \& Wang, G. S. (2010). Biodegradation of MIB and geosmin with slow sand filters. Journal of Environmental Science and Health Part A, 45(8), 951-957.

Ijadunola, J.A., Adewumi, I.O., Ashaye, A.O., Oguntade, M.I., \& Ogunlade, M.J. (2011). Comparative study on the filtration properties of local sand, rice hull and rice hull ash. Sacha Journal of Environmental Studies, 1(2), 103-129.

Joubert, E., Pillay, D., \& Balakrishna, P. (2008). Visualisation of the microbial colonisation of a slow sand filter using an Environmental Scanning Electron Microscope , Electronic Journal of Biotechnology, $11(2)$.

Langenbach, K., Kuschk, P., Horn, H., \& Kastner, M. (2009). Slow sand filtration of secondary clarifier effluent for wastewater reuse. Environmental Science \& Technology, 43(15), 5896-5901.

Lee, J. Y. (2011). Environmental issues of groundwater in Korea: implications. Journal of Environmental Conservation, 38(1), 64-74. doi: 10.1017/S0376892911000087

Liabwel, I., Kumar, S., \& Donkor, S. (2011). Technical guidelines for the construction and management of slow sand filters. Retrieved from: http://www.bsf-south-sudan.org/sites/default/files/SS+Tech+GuideSlow + Sand+Filters.pdf

Linlin, W., Xuan, Z., \& Meng, Z. (2011). Removal of dissolved organic matter in municipal effluent with ozonation, slow sand filtration and nanofiltration as high quality pre-treatment option for artificial groundwater recharge. Chemosphere,83(5), 693-699. 
Logsdon, G. S., Kohne, R., Abel, S., \& Labonde, S. (2002). Slow sand filtration for small water systems. Journal of Environmental Engineering and Science, 1(5), 339-348.

Loo, S. L., Fane, A. G., Krantz, W. B., \& Lim, T. T. (2012). Emergency water supply: A review of potential technologies and selection criteria. Water research, 46(10), 3125-3151.

Mwabi, J. K., Mamba, B. B., \& Momba, M. N. (2013). Removal of waterborne bacteria from surface water and groundwater by costeffective household water treatment systems (HWTS): A sustainable solution for improving water quality in rural communities of Africa. Water SA, 39(4), 00-00.

Nassar, A. M., \& Hajjaj, K. (2013). Purification of stormwater using sand filter. Journal of Water Resource and Protection, 5, 1007.

Pitkänen, T., Karinen, P., Miettinen, I. T., Lettojärvi, H., Heikkilä, A., Maunula, R., ... \& Heinonen-Tanski, H. (2011). Microbial contamination of groundwater at small community water supplies in Finland. Ambio, 40(4), 377-390.

Rehman, A., Naz, I., Khan, Z. U., Rafiq, M., Ali, N., Ahmad, S., .. \& Adam, K. A. O. (2012). Sequential application of plastic mediatrickling filter and sand filter for domestic wastewater treatment at low temperature condition. British Biotechnology Journal, 2(4), 179191.

Rooklidge, S. J., Burns, E. R., \& Bolte, J. P. (2005). Modeling antimicrobial contaminant removal in slow sand filtration. Water Research, 39(2), 331-339.

Sandhu, C., Grischek, T., Kumar, P., \& Ray, C. (2011). Potential for riverbank filtration in India. Clean Technologies and Environmental Policy, 13(2), 295-316. 
Torrens, A., Molle, P., Boutin, C., \& Salgot, M. (2009). Impact of design and operation variables on the performance of vertical-flow constructed wetlands and intermittent sand filters treating pond effluent. Water research, 43(7), 1851-1858.

Unger, M., \& Collins, M. R. (2006). Assessing the role of the schmutzdecke in pathogen removal in riverbank and slow sand filtration. Recent Progress in Slow Sand and Alternative Biofiltration Processes, 21.

Wotton, R. S. (2002). Water purification using sand. Hydrobiologia, 469 (1-3), 193-201. 